УдК 343.1

\author{
В. В. Лисенко, О. В. Лисенко
}

\title{
ПРОБЛЕМИ ОРГАНІЗАЦІЇ РОЗШУКУ ОСІБ, ЯКІ ПЕРЕХОВУЮТЬСЯ ВІД ОРГАНІВ ДОСУДОВОГО РОЗСЛІДУВАННЯ Й СУДУ
}

Постановка проблеми. Кримінальний процесуальний кодекс (далі - КПК) України одним із завдань (ст. 2) передбачає притягнення до кримінальної відповідальності кожного, хто вчинив кримінальне правопорушення. 3 метою ухилення від кримінального покарання значна кількість осіб переховуються від органів досудового розслідування та суду. Схожою проблемою в діяльності правоохоронних органів $є$ також установлення місця перебування осіб, які після обвинувального вироку переховуються від правосуддя та ухиляються від відбування кримінального покарання. Не менш важливим $€$ також організація діяльності правоохоронних органів із установлення місця перебування осіб, які безвісти зникли. Вищеперераховані випадки організації розшуку осіб пов'язані з учиненням злочинів. Виняток становлять випадки розшуку осіб, що зникли безвісти. Хоча в багатьох випадках зникнення безвісти є результатом учинення щодо особи злочину (зокрема вбивства) і приховування трупа або утримання як заручника, використання в «рабських» роботах тощо.

Метою статті $є$ розглянути сучасний стан щодо розшуку осіб, які переховуються від органів досудового розслідування та суду, а також головні проблеми в організації розшуку таких осіб правоохоронними органами.

Виклад основного матеріалу дослідження. Щорічно лише підрозділами Національної поліції України здійснюється розшук близько 30 тис. осіб. Кількість таких осіб має тенденцію до збільшення в тому числі через події на Сході України. У більшості випадків переховування підозрюваного (обвинуваченого) призводить до зупинення досудового розслідування чи розгляду справи в суді. Практика свідчить, що накопичення таких кримінальних проваджень, у яких підозрюваний (обвинувачений) оголошений у розшук, призводить до того, що таких осіб фактично ніхто не розшукує. Слідчими й оперативними підрозділами правоохоронних органів формально здійснюються певні заходи, спрямовані на встановлення місця перебування осіб, оголошених у розшук, які не призводять до бажаного результату.

Не вдаючись до дискусії стосовно визначення діяльності з розшуку осіб, які переховуються від органів досудового розслідування й суду, таку ді- 
яльність можна розглядати як комплекс заходів процесуального, оперативно-розшукового та організаційного характеру, які спрямовані на встановлення конкретного місця знаходження особи, котра оголошена в розшук $\mathrm{i}$ переховується від органів досудового розслідування й суду.

Увага до цього напряму діяльності правоохоронних органів викликана необхідністю усунення низки проблем з організації розшуку, удосконалення тактики пошуку таких осіб, виокремлення та аналізу складників криміналістичного забезпечення цього процесу.

Переховування осіб, які вчинили кримінальні правопорушення, від органів досудового розслідування й суду спрямоване на уникнення кримінальної відповідальності та покарання за вчинене діяння, відтермінування можливості проведення досудового розслідування або настання терміну закінчення давності притягнення їх до кримінальної відповідальності тощо.

Як свідчить аналіз діяльності правоохоронних органів, проблема організації розшуку осіб, які переховуються від органів досудового розслідування й суду, є багатоаспектною та полягає, з одного боку, в недоліках чинного кримінального процесуального законодавства; з іншого боку, збільшення кількості осіб, що переховуються від органів досудового розслідування й суду, пов'язано з недосконалим рівнем організації діяльності правоохоронних органів, високим рівнем корупції судової системи тощо. У більшості випадків щодо осіб, які переховуються від органів досудового розслідування, перед судом ставилося питання про застосування до них запобіжного заходу тримання під вартою, але з різних причин до таких осіб було застосовано інші запобіжні заходи. На рівень ефективності організації діяльності правоохоронних органів щодо розшуку осіб, які переховуються від слідства й суду, та встановлення їх місця знаходження впливає також недостатня забезпеченість їхьої діяльності відповідними криміналістичними рекомендаціями, відсутність спеціальних наукових досліджень у цьому напрямі.

У середньому в Україні питома вага розшуканих осіб, що перебували в розшуку у 2011 р., становила близько 40\%. В окремих регіонах України цей показник був нижчим від загальнодержавного (Львівській $(28,2 \%$ ), Харківській $(33,7 \%)$, Чернівецькій $(33,97 \%)$, Донецькій $(35,5 \%)$, Івано-Франківській $(35,8 \%)$, Луганській $(35,9 \%)$, Одеській $(36,7 \%)$, Київській областях $(37,3 \%)$, в АР Крим $(35,6 \%)$ та місті Києві $(35,8 \%)$.

Протягом 2014 р. правоохоронними органами встановлено місце перебування 1409 осіб, які були оголошені в розшук в інші роки, що становило 44\% від загальної кількості розшуканих. Зменшилася кількість установлення, порівняно з 2013 р., оголошених у розшук осіб, які вчинили вбивства. 3461 особи, які були оголошені в розшук, установлено 69 осіб, що становило 14,9\%. У 2013 р. місце перебування таких осіб установлено у 88 випадків, що становило $18 \%$.

Найгірші результати у 2014 р. щодо організаціі розшуку зазначених вище осіб (не встановлено жодної особи, що перебувала в розшуку за вчинення вбивства) були у Вінницькій області, де було оголошено в розшук 
9 таких осіб; Житомирській області - 6; Хмельницькій області - 8; Чернігівській області - 10; Закарпатській області - 5, відповідно [1].

Прийняття КПК України у 2012 р. та зміна багатьох положень здійснення досудового розслідування залишили невирішеними низку проблемних питань у практиці його застосування. Так, з одного боку, КПК України (ст. 281 Кримінального кодексу України) визначає, якщо під час досудового розслідування місцезнаходження підозрюваного невідомо, то слідчий, прокурор оголошує його розшук. Особливості процесуальної регламентації оголошення розшуку обвинуваченого визначаються положеннями ст. 335 КПК України. При цьому варто зазначити, що законодавець не звертає уваги на мотиви і причини переховування осіб, щодо яких оголошується розшук.

Практика розслідування злочинів викриває багато проблемних питань щодо організації розшуку з погляду застосування кримінального процесуального законодавства. Це, зокрема, стосується того, що закон визначає можливість розшуку лише підозрюваного. Тобто в цьому разі необхідно повідомити конкретну особу про підозру з дотриманням вимог, передбачених чинним кримінальним процесуальним законодавством. Однак на практиці нерідко бувають випадки, коли особа після вчинення злочину й до повідомлення їй про підозру не з'являється до органів досудового розслідування за викликами та надалі переховується.

О.В. Керевич відзначає: «... не виключено, що можливе переховування від органів досудового розслідування особи, якій не було повідомлено про підозру, проте є певні дані, що свідчать про причетність іiі до вчинення кримінального правопорушення. У практиці органів досудового розслідування питання на предмет того, яким чином оголосити таку особу в розшук, залишається відкритим» [2, с. 42]. Практики вирішують зазначені вище проблемні питання щодо оголошення в розшук через застосування можливості «заочного оголошення в розшук», тобто складання підозри стосовно конкретної особи без іï фактичного оголошення. При цьому О.В. Керевич зазначає неоднозначність такої практики і сприйняття таких заходів прокурором - процесуальним керівником [2, с. 42]. Вирішення таких проблемних питань в окремих випадках дозволяє процедура спеціального заочного провадження [3]. В окремих випадках суд відмовляє в наданні дозволу стосовно проведення спеціального досудового розслідування, оскільки ні слідчий, ні прокурор суду не надали ніяких документів, які підтверджують те, що підозрюваний переховується від органів досудового розслідування [4].

Непоодинокими випадками в судовій практиці $є$ оскарження з різних причин рішень слідчого щодо оголошення конкретної особи в розшук. Так, ухвалою Бериславського районного суду Херсонської області від 31 липня 2015 р. скасована постанова слідчого СВ Бериславського РВ УМВС України в Херсонській області про зупинення кримінального провадження й відновлено провадження через відсутність підстав для оголошення в розшук підозрюваного [5]. Ухвалою Саксаганського районного суду м. Кривого Рогу від 17 вересня 2015 р. скасована постанова від 10 липня 2015 р. слідчого СВ Саксаганського РВ УМВС в Дніпропетровській області про 
зупинення досудового розслідування та оголошення розшуку підозрюваному в кримінальному провадженню через відсутність у постанові слідчого дати, місця складання постанови й органу, якому доручено проведення такого розшуку [6].

Однак лише належне нормативно-правове визначення можливості оголошення підозрюваного (обвинуваченого) в розшук ще не повністю вирішує всі наявні проблеми, які виникають у ході фактичного здійснення розшуку таких осіб правоохоронними органами. Це стосується, зокрема, проблем обрання запобіжного заходу в разі фактичного встановлення місця знаходження осіб, що переховуються від органів досудового розслідування та суду, заборони розгляду клопотання про обрання запобіжного заходу у вигляді тримання під вартою за відсутності підозрюваного тощо.

КПК України (ст. 188) певною мірою вирішує цю проблему, надаючи прокурору, слідчому за погодженням із прокурором право звернутися з відповідним клопотанням про дозвіл на затримання підозрюваного, обвинуваченого для приводу його й розгляду питання щодо застосування запобіжного заходу у вигляді тримання під вартою. Однак виникають проблеми щодо обмеження терміну дії такого дозволу на затримання, а також особливостей переміщення (етапування) затриманої особи в разі пї затримання поза територією проведення досудового розслідування. Так, ухвалою Прилуцького міськрайонного суду Чернігівської області від 20 листопада 2015 р. задоволено клопотання щодо надання дозволу на затримання підозрюваного, 3 метою приводу в судове засідання для розгляду клопотання слідчого про обрання запобіжного заходу у вигляді тримання під вартою [7].

Варто відзначити, що розшук осіб правоохоронними органами здійснюється за трьома такими головними напрямами: 1) після вчинення злочину особа переховується й місцезнаходження невідоме, при цьому правоохоронними органами встановлені дані, що свідчать про вчинення злочину конкретною особою, яку оголошено в розшук; 2) після оголошення про підозру щодо конкретної особи обраний запобіжних захід, який не пов'язаний із триманням під вартою, при цьому особа порушила зобов'язання та переховується від органів досудового розслідування й суду; 3) після винесення обвинувального вироку й до вступу його в законну силу щодо особи був застосований запобіжний захід, не пов'язаний із триманням під вартою чи домашнім арештом і особа порушила зобов'язання та переховується від органів виконання кримінальних покарань.

Складно виокремити причини, що спонукають окремих осіб до порушення вимог обраних раніше щодо них запобіжних заходів і переховуватися від органів досудового розслідування та суду. Результати аналізу практики щодо організації розшуку осіб, які переховуються від органів досудового розслідування та суду, свідчать про наявність окремих проблем, які фактично сприяють поширенню фактів переховування підозрюваних (обвинувачених). Зокрема, зазначене вище $є$ результатом обранням щодо підозрюваного (обвинуваченого) запобіжного заходу, який не пов'язаний із триманням його під вартою. Особливо це стосується осіб, які вчинили 
тяжкі й особливо тяжкі злочини і до яких були застосовані запобіжні заходи, що дали їм змогу переховуватися від органів досудового розслідування та суду. Так, на початок 2012 р. в розшук в Україні було оголошено 420 осіб, що вчинили умисні вбивства; 600 - тяжкі тілесні ушкодження; 135 - згвалтування; 730 розбійні напади; 1085 - грабежі [8]. Причиною зазначеного вище в більшості випадків було незастосування судом щодо таких осіб запобіжного заходу (тримання під вартою), який би відповідав тяжкості вчиненого злочину. При цьому, як свідчить практика останніх подій в Україні, суди в багатьох випадках застосовували запобіжні заходи у вигляді тримання під вартою до осіб віком понад 70 років, хворих на дитячий церебральний параліч, хворих на інші тяжкі хвороби.

Важливим і дискусійним питанням щодо оголошення розшуку осіб, які переховуються від слідства та суду, є питання наявності доказовоі інформації про фактичне переховування таких осіб. I.C. Кривонос із цього приводу зазначає, що, «перед тим як оголосити розшук підозрюваного, слідчий повинен зібрати докази про вчинення правопорушення цією особою, винести відповідно до статей 276-279 КПК України стосовно неї повідомлення про підозру, а також зібрати докази, які свідчать про те, що підозрюваний переховується від слідства або місце його перебування невідоме» [9, с. 170].

Варто відзначити, що положеннями ст. 281 КПК України не визначається необхідність слідчого щодо обов'язкового збирання доказів та іншої інформації, що свідчать про фактичне переховування конкретної особи від органів досудового розслідування. Однак визначення в нормі закону положень, що «якщо ... місцезнаходження підозрюваного невідоме», необхідно розцінювати як результат того, що слідчим самостійно чи через доручення оперативним підрозділам, дільничним виконано комплекс заходів процесуального, оперативно-розшукового характеру з метою встановлення обставин переховування особи від органів досудового розслідування. Тобто слідчий збирає інформацію про те, що особа фактично переховується від органів досудового розслідування або місцеперебування іiі не встановлено. Про зазначені вище обставини може свідчити те, що особа не з'являється за викликами до органів досудового розслідування; за місцем реєстрації чи фактичного проживання не знаходиться; не з'являється за місцем роботи (навчання, лікування тощо); відсутність інформації про надходження такої особи до травматологічних пунктів, моргів; відсутність особи на стаціонарному лікування в лікувальних закладах; відсутність особи за місцем проживання сім’і, батьків, друзів тощо.

Перевірці також підлягають дані про осіб, щодо яких застосовано адміністративний арешт; затриманих на підставі положень ст. ст. 207-213 КПК України; щодо яких застосовані запобіжні заходи на підставі ст. ст. 176206 КПК України; яких поміщено до дитячого приймальника-розподільника; призваних для проходження служби в армії чи для проходження військових зборів тощо. Окрім зазначеного, підлягають перевірці дані Державної прикордонної служби України щодо перетину конкретною особою 
державного кордону України. Така інформація може бути отримана в ході проведення слідчих (розшукових) і негласних слідчих (розшукових) дій або шляхом виконання окремих доручень слідчого, надсилання запитів до відповідних установ.

I.C. Кривонос зазначає: "Доказами ухилення особи від слідства можуть стати: підтвердження про отримання повістки про виклик (в порядку ст. 133 КПК України), постанова про привід підозрюваного та результати іiї виконання (в порядку статей 140-143 КПК України), інші докази (довідки з місця роботи або навчання, паспортної служби про зміну реєстрації, отримання закордонного паспорту, закладів охорони здоров'я про можливість знаходження підозрюваного на лікуванні тощо» [9, с. 170].

Виходячи з наведеного вище, можна зазначити, що безпосередньо слідчим визначається обсяг необхідної інформації, яка буде свідчити про те, що місцезнаходження конкретної особи невідомо, і те, що така особа переховується від органів досудового розслідування. Такий обсяг інформації в кожному конкретному випадку $є$ індивідуальним і визначається безпосередньо слідчим, у провадженні якого знаходиться кримінальне провадження. Практика розслідування злочинів свідчить, що слідчі дуже детально відображають у постанові про оголошення розшуку підозрюваного інформацію стосовно проведених заходів для встановлення місцезнаходження підозрюваного до оголошення його розшуку. В окремих випадках постанова про оголошення розшуку підозрюваного становила 6 аркушів, де було детально відображено всі заходи, які здійснив слідчий і які були здійснені оперативним підрозділами за дорученням слідчого [10].

Необхідно відзначити, що прийняття рішення про оголошення особи в розшук, виходячи з положень ст. 281 КПК України, пов'язується не з наявністю відповідної доказової інформації про факт переховування особи від органів досудового розслідування, а з відсутністю в слідчого (органів досудового розслідування) інформації про фактичне місцезнаходження особи. Підставою для оголошення особи в розшук є достатність даних про те, що особа переховується від органів досудового розслідування, і те, що слідчий отримав достатньо інформації, що свідчить про переховування особи.

Практика правоохоронних органів свідчить про те, що в більшості випадків факт переховування особи від органів досудового розслідування та відсутність за місцем основного проживання підтверджується рапортом дільничного, оперативного співробітника про відсутність особи за місцем реєстрації чи фактичного проживання, за місцем роботи або даними з протоколу допиту осіб, які проживають із особою, що переховується.

Чинний КПК України не визначає безпосереднього механізму здійснення розшуку осіб, які переховуються від органів досудового розслідування та суду, і переліку спеціальних заходів процесуального чи оперативно-розшукового характеру в ході здійснення такого розшуку. Безпосередній зміст і напрями здійснення розшуку осіб визначаються слідчим, виходячи з матеріалів кримінального провадження й комплексу наявної інформації, враховуючи особливості тактики здійснення розшуку осіб, які переховуються. 
Крім зазначеного вище, кримінальний процесуальний закон також не визначає зобов'язань слідчого щодо безпосереднього здійснення ним розшуку осіб, які переховуються від органів досудового розслідування. У ч. 3 ст. 281 КПК України лише визначається можливість для слідчого доручити здійснення розшуку оперативним підрозділам. Із наведеного вище можна зробити висновок, що розшук осіб, які переховуються, може здійснюватися безпосередньо слідчим, який може доручати проведення розшуку оперативним підрозділам, або в ході здійснення спільних дій слідчого та співробітників оперативних підрозділів. На нашу думку, незважаючи на те, слідчий безпосередньо сам проводить заходи щодо розшуку, чи доручає проведення розшуку оперативним підрозділам, чи в ході спільних дій слідчих та оперативних підрозділів, відповідальність за належну організацію цього процесу та його результати покладається безпосередньо на слідчого.

Доручення слідчим на підставі ч. 3 ст. 281 КПК України проведення розшуку осіб, які переховуються від органів досудового розслідування, оперативним підрозділам Національної поліції України є найбільш ефективним і самостійним напрямом їхньої діяльності. Варто відзначити, що в більшості випадків на практиці розшук здійснюється оперативними підрозділами Національної поліції України, оскільки в їхній структурі є спеціальні підрозділи, які з використанням можливостей оперативно-розшукової діяльності здійснюють такий розшук. Спеціальні підрозділи з розшуку осіб, які переховуються від органів досудового розслідування за порушення вимог податкового законодавства, є також у підрозділах податкової міліції Державної фіскальної служби (далі - ДФС) України. Аналіз кримінальних проваджень, які знаходяться у провадженні слідчих відділів фінансових розслідувань ДФС України, засвідчили високий рівень організаційних заходів під час оголошення розшуку підозрюваного, зокрема щодо детального складання постанови про оголошення розшуку підозрюваного, відповідного доручення оперативним підрозділам із відображенням інформаціі про особу, вчинений злочин і даних, які можуть бути корисними в ході проведення розшуку підозрюваного [10-12].

Підставами здійснення оперативно-розшукових заходів у ході розшуку осіб, які переховуються від органів досудового розслідування та суду, є положення ст. 6 Закону України «Про оперативно-розшукову діяльність». $\mathrm{У}$ цій статті Закону визначено, що підставами для проведення оперативно-розшукової діяльності є наявність достатньої інформації, одержаної в установленому законом порядку, що потребує перевірки за допомогою оперативно-розшукових заходів і засобів, про «... осіб, які переховуються від органів досудового розслідування, слідчого судді, суду або ухиляються від відбування кримінального покарання».

Процесуальне оформлення доручення проведення розшуку осіб, що переховуються від органів досудового розслідування, на підставі положень ч. 3 ст. 281 КПК України здійснюється окремим дорученням слідчого 3 наданням необхідної інформації про особу, яка розшукується, обрані запобіжні заходи, місця можливого знаходження таких осіб тощо. 
Не можна повністю погодитися з думкою I.С. Кривоноса стосовно доцільності «винесення єдиної постанови про оголошення розшуку підозрюваного та зупинення розслідування». Автор викладене вище обгрунтовує тим, що більшістю положень зазначених постанов повторюється, зокрема, «сутність кримінального правопорушення та його юридична кваліфікація, відомості про особу підозрюваного, інформація про переховування особи від слідства, обраний стосовно неї запобіжний захід» [9, с. 170]. Як нам видається, складання окремої постанови про оголошення розшуку особи, що переховується від органів досудового розслідування, $є$ важливим психологічним елементом для осіб, які надалі будуть виконувати таку постанову. Особливо тоді, коли розшук такої особи доручається оперативним підрозділам Національної поліції України. Тобто з назви самої постанови будуть чітко визначатися майбутні напрями роботи з розшуку. Крім зазначеного вище, в окремій постанові про оголошення розшуку може бути детально наведено інформацію про особу, що переховується, та інформацію, що буде сприяти більш ефективній організації розшуку осіб, що переховуються від органів досудового розслідування та суду. Варто враховувати наявність у механізмі розшуку осіб, які переховуються від органів досудового розслідування, корупційного складника, оскільки практика свідчить про те, що невиконання довгий час заходів щодо розшуку конкретної особи пов'язано з приховуванням факту знаходження «розшукуваної» особи вдома, тобто особа фактично не переховувалась.

Висновки. Аналіз матеріалів діяльності правоохоронних органів про організацію розшуку осіб і встановлення їхнього місцезнаходження свідчить про наявність таких головних недоліків: 1) формальне винесення слідчим постанови про оголошення розшуку підозрюваного без належної організації фактичного пошуку; 2) доручення проведення розшуку підозрюваного оперативним підрозділам без належного контролю з боку слідчого за змістом і результатами діяльності з розшуку; 3) формальне виконання оперативними підрозділами заходів щодо встановлення особи, що розшукується, за відсутності належної взаємодії з органами досудового розслідування та обміну відповідною інформацією про обставини розшуку; 4) відсутність аналізу прорахунків щодо відповідної організації розшуку підозрюваного, обвинуваченого й мінімізації негативних чинників в організації спільної діяльності слідчих та оперативних підрозділів; 5) неприйняття слідчим відповідних процесуальних заходів у разі встановлення місцезнаходження особи, що переховується від органів досудового розслідування та суду; 6) безпідставне затягування з відкриттям або безпідставне закриття оперативно-розшукової справи «Розшук» і зняття з обліку осіб, що розшукуються, без відповідного погодження зі слідчими підрозділами; 7) формальне створення слідчо-оперативних груп для здійснення розшуку осіб, що переховуються; 8) несвоєчасне внесення інформації про осіб, які оголошені в розшук, до відповідних інформаційних обліків і затягування зі складанням необхідних обліково-реєстраційних документів; 9) недостатньо використовуються можливості Робочого апарату Українського бюро Інтерполу 
для здійснення міжнародного розшуку й установлення місця знаходження осіб, що розшукуються; 10) недостатньо використовуються можливості дипломатичних представництв України за кордоном; 11) обрання запобіжного заходу щодо підозрюваного, обвинуваченого, місце знаходження якого встановлено, не пов'язаного з тримання під вартою тощо.

Діяльність правоохоронних органів із розшуку осіб, що вчинили злочини й переховуються від органів досудового розслідування та суду, потребує відповідного забезпечення криміналістичними рекомендаціями, що дасть змогу підвищити іï ефективність. Сучасна ситуація в цьому напрямі вимагає від науковців і практиків створення відповідних алгоритмів дій із розшуку таких осіб, застосування можливостей сучасних інформаційних технологій, які дають можливість визначити точне місце знаходження особи, що розшукується.

\section{Література}

1. Узагальнення обгрунтованості зупинення досудового розслідування у кримінальних провадженнях, коли підозрюваний переховується від органів слідства з метою ухилення від кримінальної відповідальності і його місцезнаходження невідоме, за 12 місяців 2014 року : Лист Головного слідчого управління МВС України від 31 січня 2015 р. № 13/4/1-122.

2. Керевич О.В. Основні напрямки взаємодії слідчих та оперативних підрозділів ОВС при оголошенні в розшук підозрюваного / О.В. Керевич / / Вісник кримінального судочинства. 2015. - № 1. - C. 41-45.

3. Ухвала Галицького районного суду м. Львова від 31 березня 2015 р. щодо дозволу на здійснення спеціального досудове розслідування у кримінальному провадженні № 12013150010000280 від 20.02.2013 р. за відсутності особи, підозрюваної у вчиненні кримінального правопорушення, передбаченого ч. 1 ст. 115 KK України. Справа № 461/3612/15-к. Провадження № 1-кс/461/2101/15 [Електронний ресурс]. - Режим доступу : http:/ / www.reyestr.court.gov.ua/Review/53516948.

4. Ухвала Приморського районного суду м. Одеси від 23 лютого 2016 р. про відмову у клопотанні про здійснення спеціального досудового розслідування [Електронний ресурс]. - Режим доступу : http:/ / www.reyestr.court.gov.ua/Review/56053736.

5. Ухвала Бериславського районного суду Херсонської області від 31 липня 2015 р. про скасування постанови слідчого СВ Бериславського РВ УМВС України в Херсонській області про зупинення кримінального провадження № 12013230090000440 від 05.08.2014 р. і відновлення провадження із-за відсутності підстав для оголошення в розшук підозрюваного. Справа № $647 / 1216 / 15$-к. Провадження 1-кс/647/100/2015 [Електронний ресурс]. - Режим доступу : http:/ / www.reyestr.court.gov.ua/Review/44964578.

6. Ухвала Саксаганського районного суду м. Кривого Рогу від 17 вересня 2015 р. про скасування постанови від 10.08.2015 р. слідчого СВ Саксаганського РВ КМУ УМВС в Дніпропетровській області про зупинення досудового розслідування та оголошення розшуку підозрюваному по кримінальному провадженню № 42013040750000013. Справа № 214/6399/15-к [Електронний ресурс]. - Режим доступу : http:/ / www.reyestr.court.gov.ua/Review / 50538834.

7. Ухвала Прилуцького міськрайонногосуд Чернігівської області від 20 листопада 2015 р. Провадження № 1-кс/742/718/15. Єдиний унікальний № 742/4390/15-к [Електронний ресурс]. - Режим доступу : http:/ / www.reyestr.court.gov.ua/Review/53635973.

8. Довідка Головного слідчого управління МВС України «Про стан розслідування кримінальних справ, обвинувачених у яких оголошено в розшук», березень 2012 р.

9. Кривонос І.С. Здійснення розшуку підозрюваного за новим Кримінальним процесуальним кодексом України / I.C. Кривонос / / Право і безпека. - 2012. - № 4 (46). - С. 169-173.

10. Кримінальне провадження № 32013110040000078, унесене до ЄРДР 26 квітня 2013 р., за ознаками злочинів, передбачених п. 5 ст. 27, ч. 1 ст. 205, ч. 1 ст. 366, ч. 3 ст. 212 КК України. Слідчий відділ фінансових розслідувань ДПІ у Дніпровському районі ГУ Міністерства доходів і зборів доходів України у м. Києві. 
11. Кримінальне провадження № 32012090000000013, унесене до Єдиного реєстру досудових розслідувань 24 листопада 2012 р. за ознаками кримінальних правопорушень, передбачених ч. 3 ст. 212, ч.1 ст. 366 КК України. Слідчий відділ ДПС України в Івано-Франківській області.

12. Кримінальне провадження № 32013090000000007, унесене до Єдиного реєстру досудових розслідувань від 15 січня 2013 р. за ознаками кримінальних правопорушень, передбачених ч. 3 ст. 212, ч. 2 ст. 366 КК України. Слідчий відділ ДПС України в Івано-Франківській області.

\section{А нот а ц і я}

Лисенко В. В., Лисенко О. В. Проблеми організації розшуку осіб, які переховуються від органів досудового розслідування та суду. - Стаття.

У статті розглянуто сучасний стан щодо розшуку осіб, які переховуються від органів досудового розслідування та суду, а також головні проблеми в організації розшуку таких осіб правоохоронними органами.

Ключові слова: розшук підозрюваного, обвинуваченого; підстави здійснення розшуку осіб, які переховуються від слідства та суду; організація розшуку підозрюваного, обвинуваченого; недоліки організації розшуку осіб, які переховуються від слідства та суду; інформація, що свідчить про переховування осіб від органів досудового розслідування та суду.

\section{Анн о т а ция}

Лисенко В. В., Лисенко Е. В. Проблемы организации розыска лиц, скрывающихся от органов досудебного расследования и суда. - Статья.

В статье рассмотрено современное состояние относительно розыска лиц, которые скрываются от досудебного расследования и суда, а также основные проблемы в организации розыска таких лиц правоохранительными органами.

Ключевые слова: розыск подозреваемого, обвиняемого; основания осуществления розыска лиц, скрывающихся от следствия и суда; организация розыска подозреваемого, обвиняемого; недостатки организации розыска лиц, скрывающихся от следствия и суда; информация, свидетельствующая о сокрытии лиц от органов предварительного расследования и суда.

\section{S u m m a r y}

Lysenko $V . V$., Lysenko $O$. V. The problems of organizing the search for persons hiding from the bodies of pre-trial investigation and court. - Article.

There are considered the real condition in the area of looking for persons who hide from prejudicial inquiry and courts in the article. The main organizational problems of investigation concerning such people in the law enrocement authorities are described by the author

Key words: search of the suspect, the accused; Grounds for the search for persons hiding from investigation and trial; The organization of the search for a suspect or accused; Shortcomings in the organization of the search for persons hiding from the investigation and the court; Information that indicates the concealment of persons from the bodies of preliminary investigation and the court. 